\title{
Catalytic Abatement of Volatile Organic Compounds and Soot over Manganese Oxide Catalysts
}

\author{
Miguel Jose Marin Figueredo (D), Clarissa Cocuzza, Samir Bensaid, Debora Fino, Marco Piumetti *(D) \\ and Nunzio Russo
}

Citation: Figueredo, M.J.M.; Cocuzza, C.; Bensaid, S.; Fino, D.; Piumetti, M.; Russo, N. Catalytic Abatement of Volatile Organic Compounds and Soot over Manganese Oxide Catalysts. Materials 2021, 14, 4534. https://doi.org/ $10.3390 /$ ma14164534

Academic Editor: It-Meng (Jim) Low

Received: 9 July 2021

Accepted: 4 August 2021

Published: 12 August 2021

Publisher's Note: MDPI stays neutral with regard to jurisdictional claims in published maps and institutional affiliations.

Copyright: (C) 2021 by the authors. Licensee MDPI, Basel, Switzerland. This article is an open access article distributed under the terms and conditions of the Creative Commons Attribution (CC BY) license (https:// creativecommons.org/licenses/by/ $4.0 /)$.
Department of Applied Science and Technology, Politecnico di Torino, Corso Duca degli Abruzzi 24, 10129 Torino, Italy; miguel.marinfigueredo@polito.it (M.J.M.F.); clarissa.cocuzza@polito.it (C.C.); samir.bensaid@polito.it (S.B.); debora.fino@polito.it (D.F.); nunzio.russo@polito.it (N.R.)

* Correspondence: marco.piumetti@polito.it; Tel.: +39-(011)-090-4753; Fax: +39-(011)-090-4699

\begin{abstract}
A set of manganese oxide catalysts was synthesized via two preparation techniques: solution combustion synthesis $\left(\mathrm{Mn}_{3} \mathrm{O}_{4} / \mathrm{Mn}_{2} \mathrm{O}_{3}\right.$-SCS and $\mathrm{Mn}_{2} \mathrm{O}_{3}$-SCS $)$ and sol-gel synthesis $\left(\mathrm{Mn}_{2} \mathrm{O}_{3}\right.$ SG550 and $\mathrm{Mn}_{2} \mathrm{O}_{3}-\mathrm{SG} 650$ ). The physicochemical properties of the catalysts were studied by means of $\mathrm{N}_{2}$-physisorption at $-196{ }^{\circ} \mathrm{C}$, X-ray powder diffraction, $\mathrm{H}_{2}$ temperature-programmed reduction ( $\mathrm{H}_{2}$-TPR), soot-TPR, X-ray photoelectron spectroscopy (XPS) and field-emission scanning electron microscopy (FESEM). The high catalytic performance of the catalysts was verified in the oxidation of Volatile Organic Compounds (VOC) probe molecules (ethene and propene) and carbon soot in a temperature-programmed oxidation setup. The best catalytic performances in soot abatement were observed for the $\mathrm{Mn}_{2} \mathrm{O}_{3}-\mathrm{SG} 550$ and the $\mathrm{Mn}_{3} \mathrm{O}_{4} / \mathrm{Mn}_{2} \mathrm{O}_{3}$-SCS catalysts. The catalytic activity in VOC total oxidation was effectively correlated to the enhanced low-temperature reducibility of the catalysts and the abundant surface $\mathrm{O}_{\alpha}$-species. Likewise, low-temperature oxidation of soot in tight contact occurred over the $\mathrm{Mn}_{2} \mathrm{O}_{3}$-SG550 catalyst and was attributed to high amounts of surface $\mathrm{O}_{\alpha}$-species and better surface reducibility. For the soot oxidation in loose contact, the improved catalytic performance of the $\mathrm{Mn}_{3} \mathrm{O}_{4} / \mathrm{Mn}_{2} \mathrm{O}_{3}$-SCS catalyst was attributed to the beneficial effects of both the morphological structure that-like a filter-enhanced the capture of soot particles and to a probable high amount of surface acid-sites, which is characteristic of $\mathrm{Mn}_{3} \mathrm{O}_{4}$ catalysts.
\end{abstract}

Keywords: manganese oxide catalysts; soot catalytic oxidation; catalytic oxidation of volatile organic compounds; sustainable catalysts

\section{Introduction}

In recent years, the elevated concentration of pollutant substances in the air has increased the occurrence of respiratory diseases and deaths in Europe and around the world [1-4]. This encouraged the placement of regulations on the emission of PM and/or VOCs in several countries [5,6]. Volatile organic compounds are a set of substances produced every year either through natural processes or as the result of human activities (biogenic and anthropogenic, respectively) [7]. On the other hand, particulate matter is formed by elemental carbon aggregates with surface-adsorbed organic compounds, sulfur and metal oxides. It is formed due to the pyrolysis of hydrocarbons, concurrent with a defective, stoichiometric amount of oxygen, leading to the nucleation of solid particles $[8,9]$.

In order to realize the goal of reducing emissions of these pollutants to acceptable amounts, different abatement technologies have been developed. Adsorption, thermal oxidation, catalytic oxidation, and other techniques have been used to diminish VOCs emission [10-17]. The elimination of carbonaceous particulate matter has been investigated and applied primarily in the automotive sector, e.g., in diesel particulate filters [18]. Consistently, the catalytic oxidation process has demonstrated its suitability for use in the elimination of VOCs and PM by means of active catalysts. 
Concerning the elimination of VOCs, many catalytic materials, e.g., noble metals and metal oxides, have been studied. The former materials are usually characterized by remarkable catalytic performance, but are more expensive and may be subject to poisoning $[13,19]$. On the other hand, metal oxides are low-cost materials but have been shown to be catalytically active at higher temperatures $[10,13]$. The enhanced catalytic activity of transition metal oxides, as reported by multiple research investigations, has been attributed to several factors, including: high amounts of surface-chemisorbed oxygen species and enhanced oxygen mobility (associated with the catalyst reducibility) [20,21], an electron-deficient lattice with enhanced conductivity (i.e., occurrence of positive holes), and the ability of the metal to assume variable oxidation states [22]. Manganese is among the most abundant elements in the Earth's crust [23]; therefore, it constitutes a potential candidate material for the preparation of sustainable catalytic materials. Previous investigations demonstrated the outstanding catalytic performance of oxides containing manganese in different oxidation states $\left(\mathrm{Mn}_{2} \mathrm{O}_{3}, \mathrm{Mn}_{3} \mathrm{O}_{4}\right.$ and $\left.\mathrm{MnO}_{\mathrm{x}}\right)$ in the abatement of different VOCs like ethene, propene, and toluene [20]. The latter study confirmed the beneficial role played by surface-adsorbed electrophilic oxygen species and acidic sites in enhancing the catalytic activity.

In this work, a set of manganese oxide catalysts was synthesized via two different preparation techniques: solution combustion (SCS) and sol-gel (SG) syntheses. These procedures were used in the preparation of catalysts with different physicochemical and catalytic properties. The physicochemical properties of the prepared powder catalysts were studied by means of the following characterization techniques: $\mathrm{N}_{2}$-physisorption at -196 ${ }^{\circ} \mathrm{C}$, $\mathrm{X}$-ray powder diffraction, $\mathrm{H}_{2}$ temperature-programmed reduction, soot temperatureprogrammed reduction, $\mathrm{X}$-ray photoelectron spectroscopy (XPS) and scanning electron microscopy (SEM). The high performance of the prepared catalysts was verified in the oxidation of VOC probe molecules (ethene and propene) and carbon soot.

\section{Materials and Methods}

\subsection{Catalysts Preparation}

The set of powder catalysts that were synthesized were composed of manganese oxide $\left(\mathrm{MnO}_{\mathrm{x}}\right)$. The catalysts were prepared by means of two preparation techniques: (i) solution combustion synthesis (SCS) and (ii) sol-gel (SG) synthesis. The different operative conditions applied in each procedure allowed for the preparation of powder catalysts with different physicochemical characteristics.

\subsubsection{Solution Combustion Synthesis}

During the preparation of the $\mathrm{Mn}_{2} \mathrm{O}_{3}$-SCS catalyst, an aqueous solution ( $50 \mathrm{~mL}$ ) containing $0.2 \mathrm{~mol} \cdot \mathrm{L}^{-1}$ of the metal precursor, manganese nitrate tetrahydrate, $\left(\mathrm{Mn}\left(\mathrm{NO}_{3}\right)_{2} \bullet 4 \mathrm{H}_{2} \mathrm{O}\right.$, Sigma-Aldrich), and $0.2 \mathrm{~mol} \cdot \mathrm{L}^{-1}$ of citric acid $\left(\mathrm{CA}, \mathrm{C}_{6} \mathrm{H}_{8} \mathrm{O}_{7} \bullet \mathrm{H}_{2} \mathrm{O}\right.$, Sigma-Aldrich) was prepared. The solution was magnetically stirred for $10 \mathrm{~min}$ until the powders were completely dissolved. Subsequently, the solution was heated in the oven from room temperature (r.t.) to $650{ }^{\circ} \mathrm{C}\left(5^{\circ} \mathrm{C} \cdot \mathrm{min}^{-1}\right)$, and calcined isothermally for $30 \mathrm{~min}$. On the other hand, for the preparation of the $\mathrm{Mn}_{3} \mathrm{O}_{4} / \mathrm{Mn}_{2} \mathrm{O}_{3}$-SCS, a molar ratio of 1:1.25 between the Mn nitrate and $\mathrm{CA}$ was assured in the solution. After $10 \mathrm{~min}$ of stirring, the solution was heated from r.t. to $600{ }^{\circ} \mathrm{C}\left(10^{\circ} \mathrm{C} \cdot \mathrm{min}^{-1}\right)$ and calcined at a constant temperature for $30 \mathrm{~min}$. Finally, the obtained powders were ground using mortar and pestle.

\subsubsection{Sol-Gel Synthesis}

During the syntheses, manganese nitrate $\left(0.2 \mathrm{~mol} \cdot \mathrm{L}^{-1}\right)$ was dissolved with $\mathrm{CA}$ $\left(0.2 \mathrm{~mol} \cdot \mathrm{L}^{-1}\right)$ in $50 \mathrm{~mL}$ of Milli-Q water. After the powders were completely dissolved, the $\mathrm{pH}$ was increased (until $\mathrm{pH}=5$ was reached) by adding ammonium hydroxide $\left(\mathrm{NH}_{4} \mathrm{OH}\right.$, Sigma-Aldrich) dropwise. Afterward, the solution was set in a water bath and the temperature was raised (ca. $1^{\circ} \mathrm{C} \cdot \mathrm{min}^{-1}$ ) to $60^{\circ} \mathrm{C}$ under continuous stirring. The final temperature was maintained constantly for $2 \mathrm{~h}$ to enhance the nucleation and aggregation of colloidal particles. Afterward, the particles were separated from the suspension by means of vacuum 
filtration and washed with water. The resulting solid was dried at $60{ }^{\circ} \mathrm{C}$ overnight. Subsequently, it was heated $\left(5^{\circ} \mathrm{C} \cdot \mathrm{min}^{-1}\right)$ in an oven from r.t. to (i) $550{ }^{\circ} \mathrm{C}$ (for the $\mathrm{Mn}_{2} \mathrm{O}_{3}-\mathrm{SG} 550$ ) and (ii) $650{ }^{\circ} \mathrm{C}$ (for the $\mathrm{Mn}_{2} \mathrm{O}_{3}$-SG650), respectively. The resulting catalyst was gently ground using mortar and pestle.

\subsection{Catalysts Characterization}

X-ray powder diffraction (XRD) analyses were performed by means of an X'Pert Philips PW3040 diffractometer. During measurements, $\mathrm{Cu} \mathrm{K} \alpha$ radiation was utilized and the $2 \theta$ was varied in the $20^{\circ}$ to $80^{\circ}$ range; step $=0.05^{\circ} 2 \theta$ and time per step $=0.2 \mathrm{~s}$. The diffraction patterns were indexed according to the Powder Data File (PDF 2000, International Centre of Diffraction Data) Database. The average size of the crystallites was estimated using the Scherrer formula, $D=0.9 \lambda / b \cos \theta$, where $\lambda$ is the $\mathrm{Cu} \mathrm{K}_{\alpha}$ radiation wavelength, 0.9 the shape factor for spherical particles, $b$ the full width at half maximum (FWHM) in radians, and $\theta$ the angle corresponding to the observed diffraction peak.

The specific surface area $\left(\mathrm{S}_{\mathrm{BET}}\right)$, total pore volume and pore diameter were calculated by the performance of $\mathrm{N}_{2}$ physisorption at $-196{ }^{\circ} \mathrm{C}$ (Micromeritics Tristar II 3020). Before carrying out the analysis, the powders were pretreated under a $\mathrm{N}_{2}$ flow $200{ }^{\circ} \mathrm{C}$ for $2 \mathrm{~h}$. The $\mathrm{S}_{\mathrm{BET}}$ were estimated by means of the Brunauer-Emmett-Teller (BET) method. The diameter and volume of the pores $\left(D_{p}\right.$ and $V_{p}$, respectively) were calculated using the method of Barrett-Joyner-Halenda (BJH) in the data corresponding to the desorption phase.

The morphology of the powder catalysts was observed by means of a field emission scanning electron microscope (FESEM) FEI QUANTA 200F, using the following operation parameters: $\mathrm{HV}=10.00 \mathrm{kV}$, working distance $=4-5.4 \mathrm{~mm}$, intensity $=46-180 \mathrm{nA}$.

The reducibility of the catalysts was investigated through the realization of $\mathrm{H}_{2}$ temperature-programmed reduction $\left(\mathrm{H}_{2}-\mathrm{TPR}\right)$ in a ThermoQuest TPD/R/O 1100 analyzer. For the analyses, a thermal conductivity detector (TCD) was utilized. Prior to the performance of the analysis, the studied sample (ca. $20 \mathrm{mg}$ ) was subject to pretreatment under an He flow $\left(40 \mathrm{~mL} \cdot \mathrm{min}^{-1}\right)$ at $550{ }^{\circ} \mathrm{C}$ for $60 \mathrm{~min}$. Subsequently, the temperature was lowered to r.t. and the analysis was undertaken. During the analysis phase, the sample was reduced under a flow of $5 \mathrm{vol} . \%-\mathrm{H}_{2}$ in $\mathrm{Ar}\left(20 \mathrm{~mL} \cdot \mathrm{min}^{-1}\right)$ and the temperature was increased at a constant rate $\left(5^{\circ} \mathrm{C} \cdot \mathrm{min}^{-1}\right)$ from r.t. to $800{ }^{\circ} \mathrm{C}$.

The soot-TPR technique was used to analyze the reducibility of the catalyst by soot. The technique was performed inside a quartz U-tube reactor (internal diameter ID $=4 \mathrm{~mm}$ ), comprising a fixed-bed containing $45 \mathrm{mg}$ of catalyst, $5 \mathrm{mg}$ of soot (Printex-U), and $150 \mathrm{mg}$ of silica in tight contact. During the analysis, the temperature of the reactor was increased by means of a PID-controlled furnace. The intimate soot-catalyst contact condition (i.e., tight contact) was assured in a ball-milling apparatus operating at $250 \mathrm{rpm}$ for $15 \mathrm{~min}$. Before the reduction, the powder mix was pretreated under $\mathrm{N}_{2}\left(100 \mathrm{~mL} \cdot \mathrm{min}^{-1}\right)$ at $100{ }^{\circ} \mathrm{C}$ for $30 \mathrm{~min}$. Afterward, the soot-TPR was carried out under flowing $\mathrm{N}_{2}\left(100 \mathrm{~mL} \cdot \mathrm{min}^{-1}\right)$ while the temperature was increased to $700{ }^{\circ} \mathrm{C}\left(5^{\circ} \mathrm{C} \cdot \mathrm{min}^{-1}\right)$. The concentrations of $\mathrm{CO}_{2}$ and $\mathrm{CO}$ in the reactor outlet were estimated by means of NDIR analyzers.

X-ray photoelectron spectroscopy (XPS) investigations were conducted using an XPS PHI 5000 versa probe apparatus. The conditions applied during the analysis were as follows: band-pass energy $=187.85 \mathrm{eV}$, X-ray spot size $=100 \mu \mathrm{m}$, and take-off angle $=45^{\circ}$. The spectra obtained were fitted using Multipack 9.0.

\subsection{Catalytic Activity Tests}

The catalytic activity of the powders was investigated using a typical temperatureprogrammed oxidation setup. For the test, a fixed-bed containing the pelletized catalyst (diameter of pellets: $212-300 \mu \mathrm{m}$ ) was set in a quartz U-tube reactor (ID $=4 \mathrm{~mm}$ ) and the temperature of the reactor was raised using a PID-controlled furnace. The temperature of the catalytic bed was estimated with a K-type thermocouple. The reactor outlet concentrations of $\mathrm{CO}$ and $\mathrm{CO}_{2}$ were measured by non-dispersive infrared (NDIR) analyzers (ABB Uras 14. 


\subsubsection{Total Oxidation of VOC}

Before the catalytic test, the catalyst $(100 \mathrm{mg}$ ) was subjected to a degassing pretreatment under a flow of $\mathrm{N}_{2}$ at $150^{\circ} \mathrm{C}$ for $1 \mathrm{~h}$. The gaseous mixture for the test was prepared by diluting the VOC (propene or ethene) in air in order to obtain a reactor inlet concentration of $500 \mathrm{ppm}-\mathrm{VOC}, 10 \mathrm{vol} . \%-\mathrm{O}_{2}$ and the balance in $\mathrm{N}_{2}$. The flow fed to the reactor was calculated according to a constant gas hourly space velocity (GHSV) of $20,000 \mathrm{~h}^{-1}$, equivalent to a weight-to-volumetric flowrate ratio (W/F) of $0.044 \mathrm{~g} \mathrm{~h} \mathrm{~L}^{-1}$. The isothermal steps (every $30^{\circ} \mathrm{C}$ ) performed during the analysis started at $70^{\circ} \mathrm{C}$, and the temperature was increased when a stable VOC conversion was observed (in terms of $\mathrm{CO}$ and $\mathrm{CO}_{2}$ concentrations).

\subsubsection{Oxidation of Soot}

For the catalytic tests performed in loose contact between the catalyst and soot, $45 \mathrm{mg}$ of catalyst, $5 \mathrm{mg}$ of soot, and $150 \mathrm{mg}$ of inert silica were gently mixed with a spatula for $3 \mathrm{~min}$. The tight contact catalyst-soot condition was also obtained (as described previously) for the soot-TPR characterization procedure. The fixed-bed was pretreated under a flow of $\mathrm{N}_{2}\left(100 \mathrm{~mL} \cdot \mathrm{min}^{-1}\right)$ at $100^{\circ} \mathrm{C}$ for $30 \mathrm{~min}$. Then, the catalytic test was carried out under gaseous flow $\left(100 \mathrm{~mL} \cdot \mathrm{min}^{-1}\right)$ containing $10 \mathrm{vol} . \%$ of $\mathrm{O}_{2}$ and the balance in $\mathrm{N}_{2}$. The temperature in the reactor was increased at a constant heating rate $\left(5^{\circ} \mathrm{C} \cdot \mathrm{min}^{-1}\right)$ from $100{ }^{\circ} \mathrm{C}$ to $700{ }^{\circ} \mathrm{C}$.

\section{Results and Discussion}

\subsection{Material Textural Properties}

In order to examine the crystalline phases present in the powder catalysts and their characteristics, XRD analyses were conducted. The diffraction patterns harvested during this technique are reported in Figure 1.

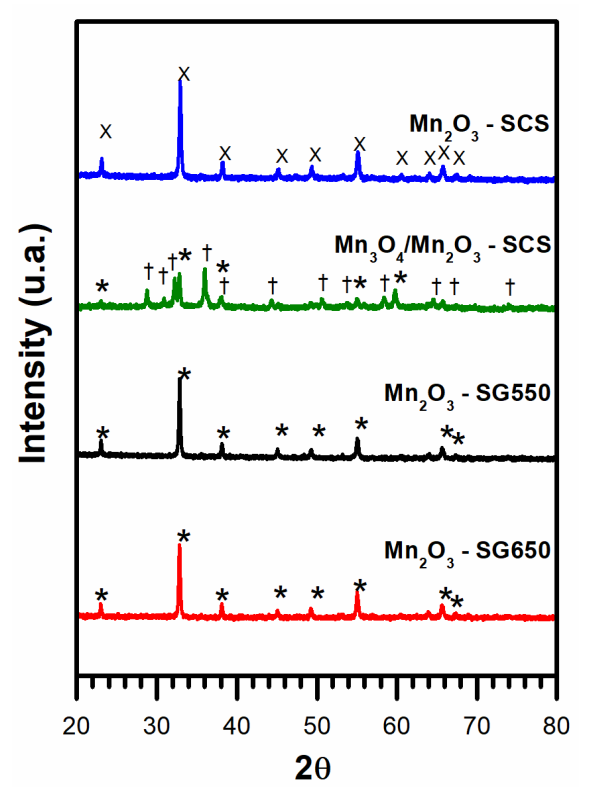

Figure 1. X-ray powder diffraction patterns of the synthesized catalysts. Assignments: $\mathrm{Mn}_{2} \mathrm{O}_{3}$ peaks $=X$ and ${ }^{*} ; \mathrm{Mn}_{3} \mathrm{O}_{4}=+$.

The patterns observed for the $\mathrm{Mn}_{2} \mathrm{O}_{3}$-SG550 and $\mathrm{Mn}_{2} \mathrm{O}_{3}$-SG650 consisted in the cubic structure of $\mathrm{Mn}_{2} \mathrm{O}_{3}$ (reference code 01-078-0390). This demonstrated that, in spite of the different calcination temperatures used after the sol-gel preparation, the resulting crystalline phase consisted in the system of $\mathrm{Mn}_{2} \mathrm{O}_{3}$. On the other hand, the pattern observed for the $\mathrm{Mn}_{2} \mathrm{O}_{3}$-SCS demonstrated the formation of the orthorhombic system of $\mathrm{Mn}_{2} \mathrm{O}_{3}$ (ref. code 01-073-1826). The $\mathrm{Mn}_{3} \mathrm{O}_{4} / \mathrm{Mn}_{2} \mathrm{O}_{3}$ catalyst showed a mixed diffraction pattern, 
mainly composed of hausmannite (ref. code 00-024-0734). However, additional diffraction lines appeared and were ascribed to the presence of $\mathrm{Mn}_{2} \mathrm{O}_{3}$ (ref. code 01-078-0390).

The textural properties of the samples are summarized in Table 1 . The results show that the SCS procedure allowed us to obtain higher specific surface areas $\left(\mathrm{S}_{\mathrm{BET}}\right)$ with respect to the SG synthesis. Obviously, obtaining higher specific surface areas is a positive outcome, since it may improve the catalytic performance in gas-phase reactions due to the higher amount of available active sites. On the other hand, larger crystallites were obtained in the samples prepared via the SG preparation than in those obtained with the SCS technique.

Table 1. Textural properties of the synthesized catalysts, calculated by means of the $\mathrm{N}_{2}$ physisorption at $-196{ }^{\circ} \mathrm{C}$ technique ${ }^{\mathrm{a}}$ and the Scherrer formula ${ }^{\mathrm{b}}$. $\mathrm{S}_{\mathrm{BET}}=$ specific surface area $\left(\mathrm{m}^{2} \mathrm{~g}^{-1}\right) ; \mathrm{Vp}=$ Total pore volume $\left(\mathrm{cm}^{3} \mathrm{~g}^{-1}\right) ; \mathrm{D}_{\mathrm{p}}=$ average pore diameter $(\mathrm{nm})$; Crystallites size $(\mathrm{nm})$.

\begin{tabular}{ccccc}
\hline Catalyst. & $\mathbf{S}_{\mathbf{B E T}}{ }^{\mathbf{a}}$ & $\mathbf{V}_{\mathbf{P}}{ }^{\mathbf{a}}$ & $\mathbf{D}_{\mathbf{P}}{ }^{\mathbf{a}}$ & Crystallites Size $^{\mathbf{b}}$ \\
\hline $\mathrm{Mn}_{2} \mathrm{O}_{3}$-SG550 & 15 & 0.12 & 32 & 67 \\
$\mathrm{Mn}_{2} \mathrm{O}_{3}$-SG650 & 11 & 0.10 & 37 & 61 \\
$\mathrm{Mn}_{2} \mathrm{O}_{3}-\mathrm{SCS}$ & 22 & 0.15 & 26 & 52 \\
$\mathrm{Mn}_{3} \mathrm{O}_{4} / \mathrm{Mn}_{2} \mathrm{O}_{3}-\mathrm{SG} 550$ & 21 & 0.13 & 23 & $37 / 53$ \\
\hline
\end{tabular}

The morphologies of the catalyst as observed in the FESEM are summarized in Figure 2. In general, the micrographs show the formation of mesoporous structures during both synthesis procedures. Moreover, the catalysts prepared via SCS were characterized by a mesoporous structure. This coincided with the highest surface areas observed, suggesting the formation of highly porous, sponge-like structures during the SCS technique. Conversely, the powders prepared via SG synthesis were formed by slim nanoplates. Interestingly, the micrographs showed that the nanoplates formed in the sol-gel synthesis contained a porous interior enclosed in an external shell.
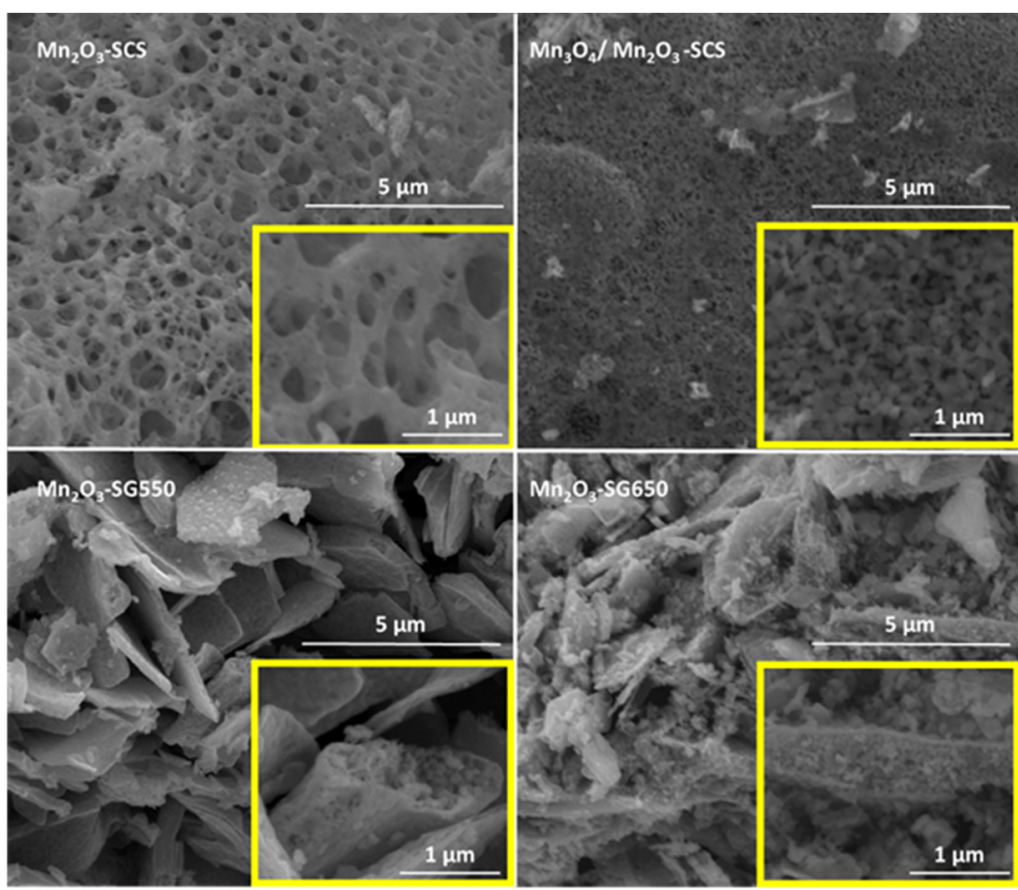

Figure 2. FESEM micrographs of the prepared catalysts and the corresponding magnifications (in the yellow frames).

\subsection{Temperature-Programmed Analyses}

The reducibility of the catalysts was estimated under a flow of 5 vol.\%- $\mathrm{H}_{2}$ in $\mathrm{Ar}$ in the range $100-800{ }^{\circ} \mathrm{C}$. The reduction profiles obtained are shown in Figure 3. As a 
general behavior, the samples composed by $\mathrm{Mn}_{2} \mathrm{O}_{3}$ showed a two-peak reduction profile. Therefore, in this case, the reduction signal with maxima between $350-383{ }^{\circ} \mathrm{C}$ could be ascribed to the reduction step $\mathrm{Mn}_{2} \mathrm{O}_{3} \rightarrow \mathrm{Mn}_{3} \mathrm{O}_{4}$. Meanwhile, the peak which occurred at higher temperatures corresponded to the final reduction step $\mathrm{Mn}_{3} \mathrm{O}_{4} \rightarrow \mathrm{MnO}[20$,24-26]. Consistently, this result confirmed the elevated amount of $\mathrm{Mn}$ species with oxidation states $3+$ in samples composed by $\mathrm{Mn}_{2} \mathrm{O}_{3}$ (as observed during XRD analyses). Additionally, the formation of larger particles during SG synthesis (as estimated by means of Scherrer formula) seemed related to a decreased intensity of the first reduction peak (i.e., the lowtemperature peak) and the translation of the second signal to higher temperatures. In accordance with the literature, this could be associated with the formation of larger particles of $\mathrm{Mn}_{2} \mathrm{O}_{3}$ which could be more resistant to reduction $[27,28]$.

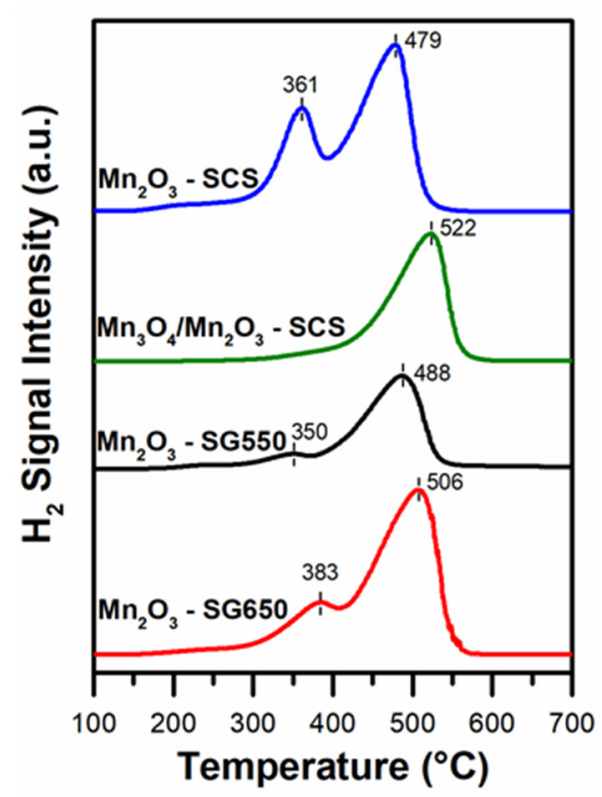

Figure $3 . \mathrm{H}_{2}-\mathrm{TPR}$ of the synthesized catalysts.

On the other hand, the small reduction signal of the $\mathrm{Mn}_{3} \mathrm{O}_{4} / \mathrm{Mn}_{2} \mathrm{O}_{3}-\mathrm{SCS}$ which began around $300{ }^{\circ} \mathrm{C}$ may be attributed to the presence of $\mathrm{Mn}^{3+}$ species in $\mathrm{Mn}_{2} \mathrm{O}_{3}$ crystals, as confirmed in the XRD studies (vide supra). On the whole, a reducibility trend (in terms of low-temperature reduction signal) was drawn as follows: $\mathrm{Mn}_{2} \mathrm{O}_{3}$-SG550 $>\mathrm{Mn}_{2} \mathrm{O}_{3}$-SCS > $\mathrm{Mn}_{2} \mathrm{O}_{3}$-SG650 > $\mathrm{Mn}_{3} \mathrm{O}_{4} / \mathrm{Mn}_{2} \mathrm{O}_{3}$-SCS.

The reducibility of the catalysts by soot in tight contact condition was studied in the absence of oxygen (see Figure 4). Under this condition, the oxidation of carbonaceous matter took place by means of the oxygen species composing the catalyst. Various signal maxima of $\mathrm{CO}_{2}$ appeared in the whole range of temperatures analyzed. The first signal (observed only for the $\mathrm{Mn}_{2} \mathrm{O}_{3}$-SG550) appeared around $240{ }^{\circ} \mathrm{C}$ and was attributed to the desorption of $\mathrm{CO}_{2}$ bonded to basic sites of manganese oxide [29]. On the other hand, the signal observed at $\mathrm{T}<450{ }^{\circ} \mathrm{C}$ was attributed to the oxidation of soot $\left(\mathrm{C}+\mathrm{O}_{\alpha} \rightarrow \mathrm{CO}+\mathrm{O}_{\alpha}\right.$ $\rightarrow \mathrm{CO}_{2}$ ) by means of chemisorbed $\mathrm{O}^{2-}$, while the signal that occurred between 450 and $550{ }^{\circ} \mathrm{C}$ was associated to other electrophilic oxygen species (e.g., $\mathrm{O}^{-}$and $\mathrm{O}_{2}{ }^{2-}$ ) [30,31]. At higher temperatures, the oxidation of soot occurred as a result of the release of oxygen present in the bulk $\left(\mathrm{C}+\mathrm{O}_{\beta} \rightarrow \mathrm{CO}+\mathrm{CO}_{2}\right)$, coinciding with the appearance of $\mathrm{CO}$ (see Figure $4 \mathrm{~b}$ ). The latter took place due to the slow diffusion of oxygen from the bulk to the surface, under which condition some of the reaction intermediate (thus the $\mathrm{CO}$ ) did not convert to $\mathrm{CO}_{2}$ [32]. It is worth noting the lower signal intensity in the case of the catalysts calcined at $650{ }^{\circ} \mathrm{C}$ with respect to the signal of the $\mathrm{Mn}_{2} \mathrm{O}_{3}$-SG550. This result suggested that the higher calcination temperature may have stabilized the crystalline structure of the catalysts, thus leading to an overall lower reducibility. Consistently, the overall reducibility 
of the catalysts by soot followed this trend: $\mathrm{Mn}_{2} \mathrm{O}_{3}$-SG550 $>\mathrm{Mn}_{2} \mathrm{O}_{3}$-SG650 $\approx \mathrm{Mn}_{2} \mathrm{O}_{3}$-SCS $\approx \mathrm{Mn}_{3} \mathrm{O}_{4} / \mathrm{Mn}_{2} \mathrm{O}_{3}$-SCS.

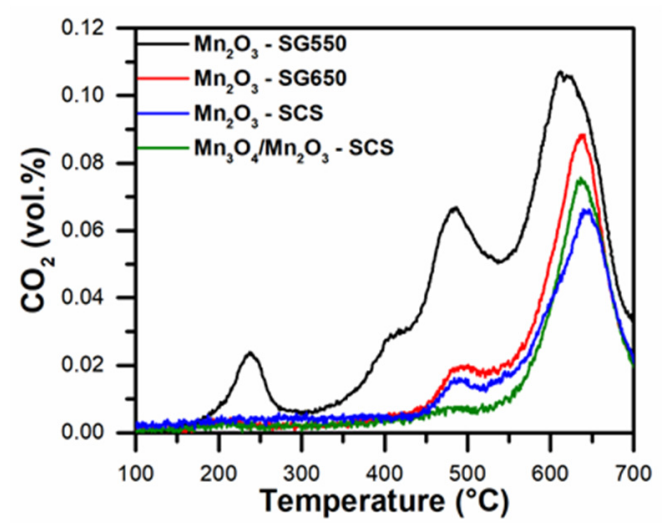

(a)

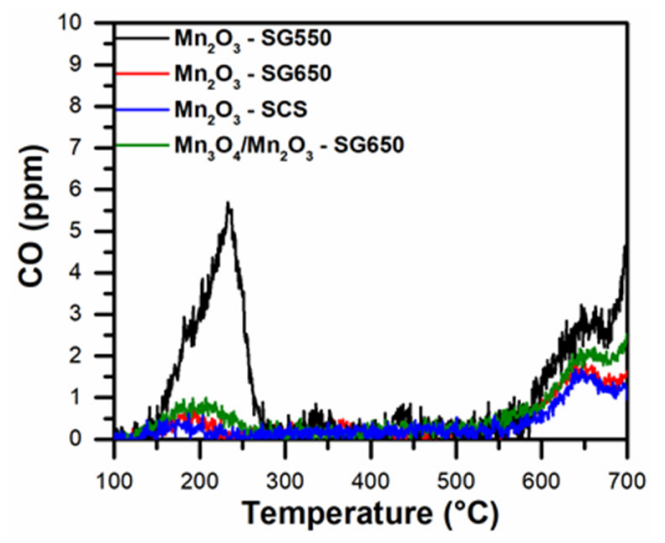

(b)

Figure 4. (a) $\mathrm{CO}_{2}$ and (b) $\mathrm{CO}$ profiles observed during the soot-TPR analyses of the prepared catalysts.

\subsection{X-ray Photoelectron Spectroscopy}

The spectra obtained during the XPS investigations are summarized in Figure 5. The spectra obtained in the $\mathrm{O} 1 \mathrm{~s}$ core level and the respective deconvolution are shown in Figure 5a. As a whole, the spectra were characterized by a signal with two maxima at different binding energy (BE) values, each one assigned to different oxygen species. The signals that appeared at low binding energy (between 529.6 and $529.9 \mathrm{eV}$ ) were attributed to nucleophilic lattice oxygen $\left(\mathrm{O}^{2-}\right)$ bonded to $\mathrm{Mn}$ (thus $\mathrm{O}_{\beta}$ species) [33]. On the other hand, the signal maxima centered between 531.2 and $531.4 \mathrm{eV}$ was ascribed to electrophilic oxygen species (e.g., $\mathrm{O}^{-}$or $\mathrm{O}^{2-}$ ) or $\mathrm{OH}$ groups located over the surface of the catalyst $[21,34]$. The amount of $\mathrm{O}_{\alpha}$ and $\mathrm{O}_{\beta}$ species (see Table 2) were estimated according to the deconvolution of the spectra. A decreasing trend of the $\mathrm{O}_{\alpha} / \mathrm{O}_{\beta}$ ratio was observed as follows: $\mathrm{Mn}_{2} \mathrm{O}_{3}$-SG550 $>\mathrm{Mn}_{2} \mathrm{O}_{3}$-SCS $>\mathrm{Mn}_{2} \mathrm{O}_{3}$-SG650 $\approx \mathrm{Mn}_{3} \mathrm{O}_{4} / \mathrm{Mn}_{2} \mathrm{O}_{3}$-SCS. Remarkably, the increased amount of $\mathrm{O}_{\alpha}$ has been correlated in the literature to total oxidation of hydrocarbons $[20,35,36]$.

Table 2. Relative percentages (at.\%) of oxygen species calculated from the deconvolution of the $\mathrm{O} 1 \mathrm{~s}$ XPS spectra.

\begin{tabular}{|c|c|c|c|c|c|}
\hline Catalyst & $\begin{array}{c}\mathrm{O}_{\alpha}, \mathrm{OH}^{-} \mathrm{BE} \\
(\mathrm{eV})\end{array}$ & $\begin{array}{c}\mathrm{O}_{\alpha} \\
\text { (at.\%) }\end{array}$ & $\begin{array}{c}\mathrm{O}_{\beta} \mathrm{BE} \\
(\mathrm{eV})\end{array}$ & $\begin{array}{c}\mathrm{O}_{\beta} \\
\text { (at.\%) }\end{array}$ & $\mathrm{O}_{\alpha} / \mathrm{O}_{\beta}$ \\
\hline $\mathrm{Mn}_{2} \mathrm{O}_{3}$-SG550 & 531.4 & 56.7 & 529.8 & 43.3 & 1.31 \\
\hline $\mathrm{Mn}_{2} \mathrm{O}_{3}-\mathrm{SG} 650$ & 531.2 & 31.8 & 529.6 & 68.2 & 0.47 \\
\hline $\mathrm{Mn}_{2} \mathrm{O}_{3}$-SCS & 531.3 & 38.5 & 529.6 & 61.5 & 0.63 \\
\hline $\mathrm{Mn}_{3} \mathrm{O}_{4} / \mathrm{Mn}_{2} \mathrm{O}_{3}-\mathrm{SG} 550$ & 531.4 & 31.8 & 529.9 & 68.2 & 0.47 \\
\hline
\end{tabular}

Additionally, the XP spectra in the Mn 2p core level were measured, and are included in Figure $5 b$. The signal observed at higher binding energy was attributed to the $2 p_{1 / 2}$ level, whereas the signal located at lower binding energy (between 637.8-647.4 eV) corresponded to the $2 \mathrm{p}_{3 / 2}$ level. As reported in the literature, the deconvolution of the latter signal can be used for estimating the relative amount of $\mathrm{Mn}^{\mathrm{x}}$ species (where $\mathrm{x}=2+; 3+$ and $4+$ ) in the sample $[20,21,37]$. The spectra deconvolution (numerical data not reported for the sake of brevity) confirmed the predominance of $\mathrm{Mn}$ species with oxidation state $3+$ for the samples composed mainly by $\mathrm{Mn}_{2} \mathrm{O}_{3}$. On the other hand, the calculations on the amount of $\mathrm{Mn}^{3+}$ and $\mathrm{Mn}^{2+}$, as expected, revealed similar amounts as the sample composed by the spinel $\mathrm{Mn}_{3} \mathrm{O}_{4}$. 


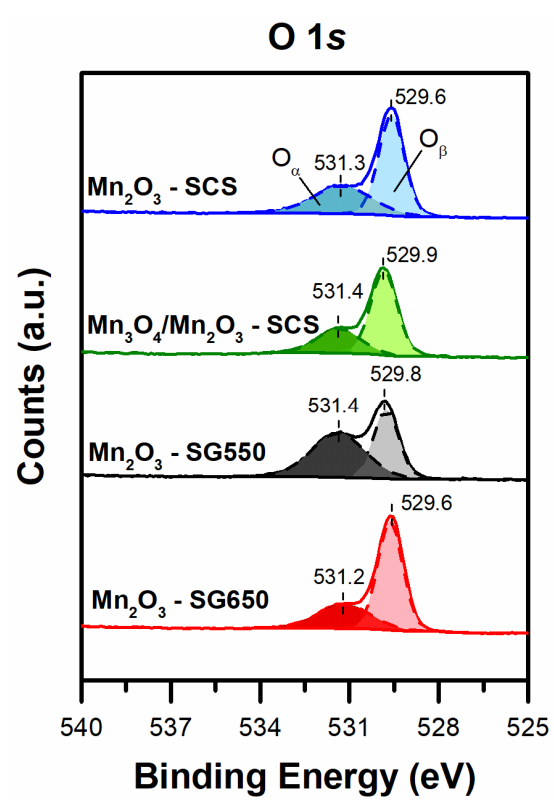

(a)

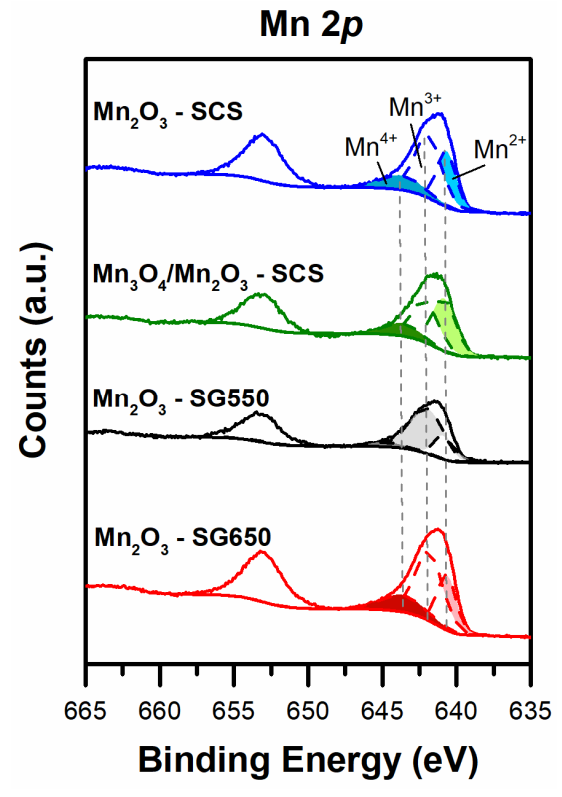

(b)

Figure 5. XPS spectra in the (a) O 1s (section a) and (b) Mn 2p core level.

\subsection{Catalytic Activity}

\subsubsection{Oxidation of VOCs}

The catalytic performance of the prepared catalysts was evaluated in the oxidation of carbon soot precursors (i.e., volatile organic compounds). During the testing of the samples, propene and ethene were used as probe VOC molecules. The catalytic performances observed during the tests are summarized in Figures 6 and 7a. The whole set of catalysts completely converted the VOCs at lower temperatures, with respect to the blank test that had no catalyst. The VOC conversion rates of the prepared catalysts are summarized in Table 3.

Table 3. Propene and ethene specific reaction rates over the prepared catalysts.

\begin{tabular}{ccc}
\hline Catalyst & $\begin{array}{c}\mathbf{r}_{\text {propene }}{ }^{\mathbf{a}} \\
\left(\mu \mathbf{m o l ~ h} \mathbf{~ h}^{-\mathbf{1}} \mathbf{~ m}^{-\mathbf{2}}\right)\end{array}$ & $\begin{array}{c}\mathbf{r}_{\text {ethene }} \mathbf{b} \\
\left(\mu \mathbf{m o l ~ h} \mathbf{~}^{-\mathbf{1}} \mathbf{~ m}^{-\mathbf{2}}\right)\end{array}$ \\
\hline $\mathrm{Mn}_{2} \mathrm{O}_{3}$-SG550 & 0.94 & 1.67 \\
$\mathrm{Mn}_{2} \mathrm{O}_{3}$-SG650 & 0.49 & 1.13 \\
$\mathrm{Mn}_{2} \mathrm{O}_{3}-\mathrm{SCS}$ & 0.35 & 1.04 \\
$\mathrm{Mn}_{3} \mathrm{O}_{4} / \mathrm{Mn}_{2} \mathrm{O}_{3}$-SG550 & 1.48 & 1.69 \\
\hline
\end{tabular}

a calculated at $130{ }^{\circ} \mathrm{C} ;{ }^{\mathrm{b}}$ calculated at $160^{\circ} \mathrm{C}$.

The following trend can be outlined for the catalytic activity during the oxidation of propene: $\mathrm{Mn}_{3} \mathrm{O}_{4} / \mathrm{Mn}_{2} \mathrm{O}_{3}$-SCS $>\mathrm{Mn}_{2} \mathrm{O}_{3}$-SG550 $>\mathrm{Mn}_{2} \mathrm{O}_{3}$-SCS $>\mathrm{Mn}_{2} \mathrm{O}_{3}$-SG650. The general performances of the catalysts prepared via SG showed catalytic improvement when a lower calcination temperature was utilized. In fact, the higher temperature may have caused the sintering of the catalyst, leading to the reduction of the catalyst's surface area (as reported in Table 1). Therefore, this finding confirms the key role of calcination temperature in the preparation of catalysts active in the oxidation of VOCs. The most active catalyst in the oxidation of propene was composed mainly of the spinel structure $\mathrm{Mn}_{3} \mathrm{O}_{4}$ (coupled $\mathrm{Mn}^{3+} \mid \mathrm{Mn}^{2+}$ species) with the smallest crystallite size of the prepared set of catalysts (approximately $37 \mathrm{~nm}$ for the $\mathrm{Mn}_{3} \mathrm{O}_{4}$ ). In this sense, the outstanding activity of the $\mathrm{Mn}_{3} \mathrm{O}_{4} / \mathrm{Mn}_{2} \mathrm{O}_{3}-\mathrm{SCS}$ catalyst could have been associated with the presence of small crystallites of hausmannite that, according to the literature, can promote an elevated occurrence of crystallite edges and corners and thus, more defective structures active in the 
oxidation reaction [38,39]. It is worth noting that, among the catalysts classified as pure $\mathrm{Mn}_{2} \mathrm{O}_{3}$ (by means of XRD), the catalytic trend coincided with a decreasing trend in two parameters: (i) low-temperature reducibility, and (ii) the amount of surface-chemisorbed $\mathrm{O}_{\alpha}$-species. In fact, the catalytic performance data were fitted and showed a linear behavior dependent on the low-temperature reduction peak (see Figure $6 \mathrm{~b}$ ), thus confirming the correlation between reducibility and improved catalytic activity in propene oxidation (in terms of $\mathrm{T}_{10 \%}, \mathrm{~T}_{50 \%}$ and $\mathrm{T}_{90 \%}$, thus the temperatures for achieving a conversion of $10 \%$, $50 \%$ and $90 \%$, respectively).



(a)

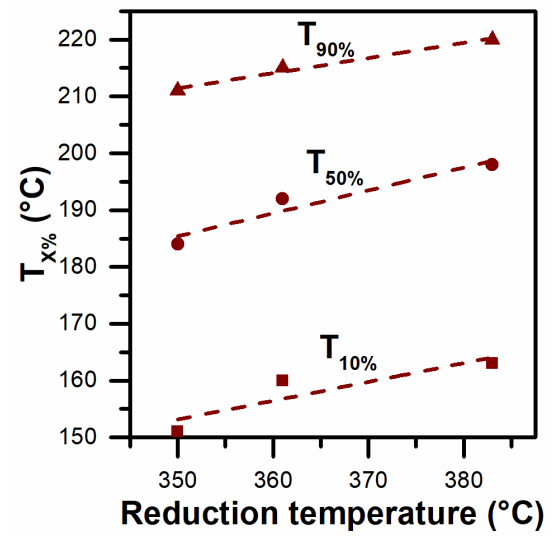

(b)

Figure 6. (a) Catalytic performances in the oxidation of $\mathrm{C}_{3} \mathrm{H}_{6}$ and (b) correlation between the lowtemperature reduction peak and the catalytic performance in $\mathrm{C}_{3} \mathrm{H}_{6}$ oxidation (over $\mathrm{Mn}_{2} \mathrm{O}_{3}$ catalysts) in terms of $\mathrm{T}_{10 \%}, \mathrm{~T}_{50 \%}$ and $\mathrm{T}_{90 \%}$.



(a)



(b)

Figure 7. (a) Catalytic performances in the oxidation of $\mathrm{C}_{2} \mathrm{H}_{4}$ and (b) correlation between the lowtemperature reduction peak and the catalytic performance in $\mathrm{C}_{2} \mathrm{H}_{4}$ oxidation (over $\mathrm{Mn}_{2} \mathrm{O}_{3}$ catalysts) in terms of $\mathrm{T}_{10 \%}, \mathrm{~T}_{50 \%}$ and $\mathrm{T}_{90 \%}$.

The $\mathrm{Mn}_{2} \mathrm{O}_{3}$-SG550 catalyst-in spite of having an intermediate surface area value with respect to the whole set of catalysts-showed the best overall catalytic performance in the abatement of ethene (see Figure 7a). Considering the overall catalytic performance and the low-temperature ethene reaction rates, the following catalytic activity trend in the oxidation of ethene was drawn: $\mathrm{Mn}_{2} \mathrm{O}_{3}$-SG550 $>\mathrm{Mn}_{3} \mathrm{O}_{4} / \mathrm{Mn}_{2} \mathrm{O}_{3}$-SCS $>\mathrm{Mn}_{2} \mathrm{O}_{3}$-SCS $>$ $\mathrm{Mn}_{2} \mathrm{O}_{3}$-SG650. As a whole, the catalytic activity seemed to be attributable to the relative amount of active chemisorbed $\mathrm{O}_{\alpha}$-species (as verified via XPS, vide supra) and (in the case of the $\mathrm{Mn}_{2} \mathrm{O}_{3}$ catalysts) the low-temperature reducibility of the catalysts (see Figure $7 \mathrm{~b}$ ).

Accordingly, the results demonstrate the key role played by active $\mathrm{O}_{\alpha}$-species and catalyst reducibility in the elimination of ethene. In fact, according to the literature, a 
number of these species may promote VOC catalytic oxidation at lower temperatures in conjunction with low-temperature reducibility $[20,21,27,40]$. Overlooking the catalytic behavior observed during the abatement of the VOCs, it was evident that catalysts that belong to the same group or family could present different catalytic performances according to the abated molecule. In other words, the catalytic activity for a specific reaction may depend on a wide set of physicochemical properties (reducibility, surface acidity, size of crystallites, amount of chemisorbed oxygen species, etc.). Consequently, it may be useful to speculatively select a catalyst for a specific reaction according to a single physicochemical property or catalytic results obtained with other molecules. In conclusion, the prepared catalysts showed high levels of catalytic activity at relatively low temperatures in the elimination of VOCs (i.e., carbon soot precursors).

\subsubsection{Oxidation of Carbonaceous Matter (Soot)}

The catalytic activity of the oxides was tested in the oxidation of carbonaceous matter in loose or tight contact. The former condition was assured by a delicate mixing of the powders (soot, catalyst, inert silica), whereas the most intimate solid-solid interactions (i.e., tight contact) were enhanced by means of the ball-milling process. The curves of the soot catalytic conversions of the prepared catalysts are included in Figure 8.

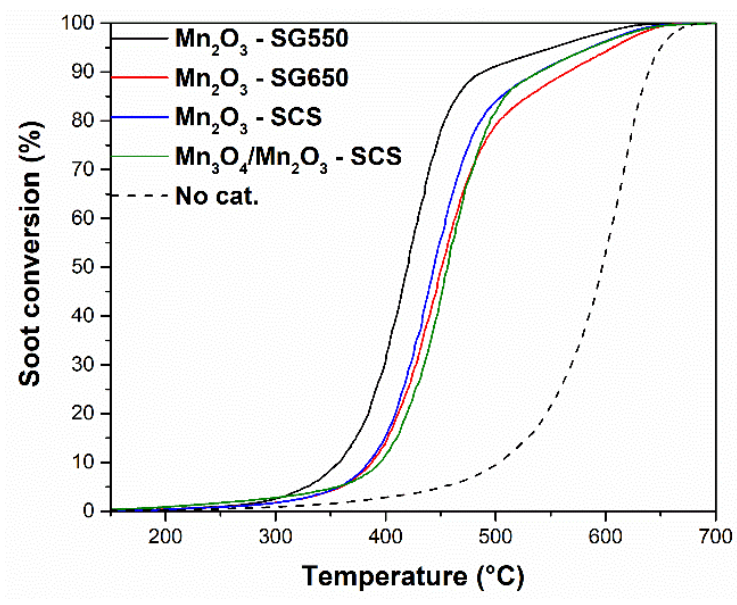

(a)

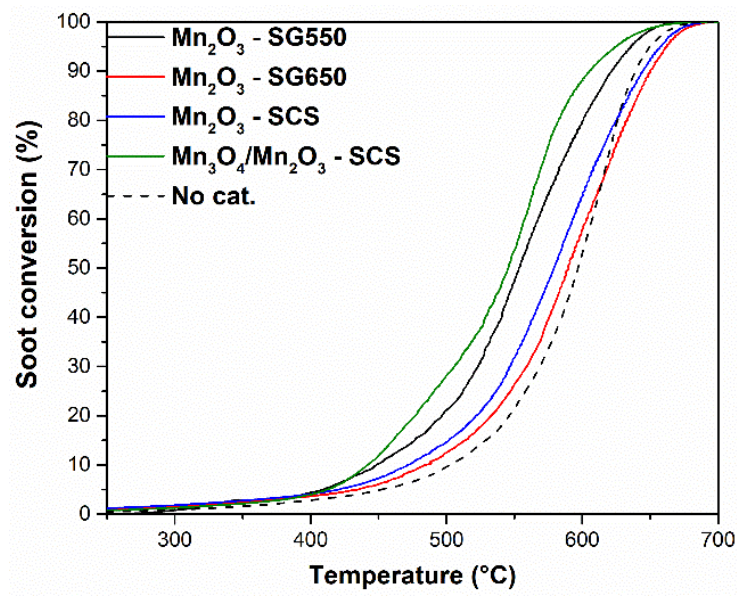

(b)

Figure 8. Catalytic conversion of carbon soot as a function of the temperature in (a) "tight" and (b) "loose" contact conditions.

During all catalytic tests, $\mathrm{CO}_{2}$ was the main oxidation product, while the concentration of $\mathrm{CO}$ remained low (or even imperceptible) in most cases. The soot oxidation was a solidsolid reaction; therefore, enhancing catalyst-soot contact played a key role in estimations of soot oxidation kinetics [41]. In this sense, the conversions obtained in tight condition showed the intrinsic activity of the catalytic surface. Consistently, the results obtained in tight contact demonstrated that the catalytic performance of the active phase in the catalysts calcined at higher temperatures $\left(\mathrm{T}>600^{\circ} \mathrm{C}\right.$; see the blue, red, and green lines) are rather similar. On the other hand, the best performance was observed in the catalyst calcined at the lowest temperature, approximately $550^{\circ} \mathrm{C}$ (i.e., the $\mathrm{Mn}_{2} \mathrm{O}_{3}-\mathrm{SG} 550$ ). This catalyst achieved $10 \%$ and $50 \%$ of the soot conversion, respectively, at temperatures of approximately $25^{\circ} \mathrm{C}$ below the other catalysts. These results suggested that the higher calcination temperatures may have enhanced a sintering process that diminished the whole number of soot- $\mathrm{MnO}_{\mathrm{x}}$ contact points present in the catalysts. On the other hand, the reducibility of the catalysts was diminished in the catalysts calcined at higher temperatures (as demonstrated by sootTPR analyses, vide supra), which also correlated with their lower catalytic performance in tight contact conditions. Furthermore, the best catalyst contained the highest amount of active $\mathrm{O}_{\alpha}$-species, which are important for starting soot oxidation [18]. The results, 
therefore, demonstrate the remarkable importance of an elevated amount of surface $\mathrm{O}_{\alpha}$ species and improved catalyst reducibility in the carbon soot oxidation process.

The loose contact conditions were more representative of real contact conditions in catalytic traps [41]. The results showed similar catalytic activities for the $\mathrm{Mn}_{2} \mathrm{O}_{3}-\mathrm{SG} 650$ and the $\mathrm{Mn}_{2} \mathrm{O}_{3}$-SCS. However, under this contact condition, the soot conversion of the catalyst containing the spinel $\mathrm{Mn}_{3} \mathrm{O}_{4}$ overcame the catalytic performance of the $\mathrm{Mn}_{2} \mathrm{O}_{3}$-SG550. This suggested that, in spite of the higher temperature treatment of the former catalyst, the contact points between soot and $\mathrm{Mn}_{3} \mathrm{O}_{4}$ greatly enhanced the catalytic performance. Accordingly, this further suggests that the contact points were readily accessible for the soot without favoring an intimate soot-catalyst contact. This could be associated to the sponge-like morphology of the catalyst, characteristic of the SCS preparation technique. This morphology resembled a catalytic trap or a filter. In this case, it may have allowed an easier path for soot to penetrate the structure of the catalyst and remain trapped inside it, with respect to the void nanoplates. Accordingly, this may have also enhanced the occurrence of contact points for the catalytic oxidation of soot. Moreover, in previous studies, $\mathrm{Mn}_{3} \mathrm{O}_{4}$ (and mixed oxides containing $\mathrm{Mn}_{3} \mathrm{O}_{4}$ ) were demonstrated to host an increased amount of acid sites with respect to other $\mathrm{MnO}_{\mathbf{x}}$ [20,42]. Lewis acid sites are characterized by superficial (oxygen deficient) metal cations. These sites can play a key role in the adsorption of the oxygen needed for the oxidation reaction, its surface diffusion, and the final transfer to soot, Therefore, these sites can be correlated to soot oxidation performance [43,44]. Consistently, the elevated activity in loose catalyst-soot contact was ascribed to the combined promoting effects of the sponge-type morphology (acting like a powder filter or trap) and a probable increased amount of acid sites in contact with the soot of the $\mathrm{Mn}_{3} \mathrm{O}_{4} / \mathrm{Mn}_{2} \mathrm{O}_{3}$-SCS catalyst. The overall results demonstrated the remarkable effectiveness of sustainable $\mathrm{MnO}_{\mathrm{x}}$-based oxides in the elimination of solid carbon soot and its organic precursors, VOCs.

\section{Conclusions}

A set of manganese oxide catalysts was synthesized via two preparation techniques: solution combustion synthesis $\left(\mathrm{Mn}_{3} \mathrm{O}_{4} / \mathrm{Mn}_{2} \mathrm{O}_{3}\right.$-SCS and $\mathrm{Mn}_{2} \mathrm{O}_{3}$-SCS $)$ and sol-gel synthesis $\left(\mathrm{Mn}_{2} \mathrm{O}_{3}\right.$-SG550 and $\left.\mathrm{Mn}_{2} \mathrm{O}_{3}-\mathrm{SG} 650\right)$. These synthesis procedures allowed for the preparation of catalysts with different physicochemical and catalytic properties. Overall, the best catalytic performances in the abatement of solid carbon soot and VOCs were observed in $\mathrm{Mn}_{2} \mathrm{O}_{3}$-SG550 and $\mathrm{Mn}_{3} \mathrm{O}_{4} / \mathrm{Mn}_{2} \mathrm{O}_{3}$-SCS catalysts. Concerning the catalytic oxidation of the studied VOCs, the best catalytic performances were associated with the following parameters:

1. The elevated relative amounts of active surface $\mathrm{O}_{\alpha}$ species, which can significantly improve the total catalytic oxidation of hydrocarbons at low temperatures.

2. The improved low-temperature reducibility of the catalysts due to the enhanced mobility of the oxygen taking part in the oxidation reactions.

3. The appearance of small crystallites, which may contain an elevated amount of surface defects that enhance the catalytic performance.

The influence of the aforementioned characteristics (i and ii) on the oxidative performance of the catalysts in the solid carbon soot oxidation reaction was demonstrated in the present study. Accordingly, in tight contact conditions, the best catalytic performance in soot oxidation was observed in the catalyst containing the highest amount of $\mathrm{O}_{\alpha}$ species and exhibiting better reducibility, i.e., the $\mathrm{Mn}_{2} \mathrm{O}_{3}$-SG550. This result highlighted the beneficial effect of those two parameters on the intrinsic oxidative activity of the catalysts surface. On the other hand, the outstanding catalytic activity of the $\mathrm{Mn}_{3} \mathrm{O}_{4} / \mathrm{Mn}_{2} \mathrm{O}_{3}$-SCS in loose contact was attributed to the combined effect of (i) a filter-like morphology (that may have improved the capture of soot particles) and (ii) a probable high amount of surface acid sites, which are characteristic of $\mathrm{Mn}_{3} \mathrm{O}_{4}$ catalysts. 
Author Contributions: Conceptualization, supervision M.P.; methodology, M.J.M.F.; formal analysis, M.J.M.F. and C.C.; investigation, M.J.M.F. and C.C.; supervision and writing review N.R., S.B. and D.F.; data curation, M.J.M.F. and C.C.; writing—original draft preparation, M.J.M.F.; writing—review and editing, M.J.M.F. All authors have read and agreed to the published version of the manuscript.

Funding: This project has received funding from the European Union's Horizon 2020 research and innovation programme under grant agreement No 768692.

Institutional Review Board Statement: Not applicable.

Informed Consent Statement: Not applicable.

Data Availability Statement: Not applicable.

Conflicts of Interest: The authors declare no conflict of interest.

\section{References}

1. Sicard, P.; Khaniabadi, Y.O.; Perez, S.; Gualtieri, M.; De Marco, A. Effect of O3, PM10 and PM2.5 on cardiovascular and respiratory diseases in cities of France, Iran and Italy. Environ. Sci. Pollut. Res. 2019, 26, 32645-32665. [CrossRef] [PubMed]

2. Spiteri, J.; Von Brockdorff, P. Transboundary air pollution and respiratory disease mortality: Evidence from European countries. J. Econ. Stud. 2020. [CrossRef]

3. Viegi, G.; Baldacci, S.; Maio, S.; Fasola, S.; Annesi-Maesano, I.; Pistelli, F.; Carrozzi, L.; La Grutta, S.; Forastiere, F. Health effects of air pollution: A Southern European perspective. Chin. Med. J. 2020, 133, 1568-1574. [CrossRef] [PubMed]

4. Vohra, K.; Vodonos, A.; Schwartz, J.; Marais, E.A.; Sulprizio, M.P.; Mickley, L.J. Global mortality from outdoor fine particle pollution generated by fossil fuel combustion: Results from GEOS-Chem. Environ. Res. 2021, 195, 110754. [CrossRef]

5. Directive 2008/50/EC of the European Parliament and of the Council of 21 May 2008 on Ambient Air Quality and Cleaner Air for Europe. EUR-Lex. 2008. Available online: https:/ / eur-lex.europa.eu/eli/dir/2008/50/oj.

6. Particulate Matter (PM) Implementation Regulatory Actions. United States Environmental Protection Agency. 2016. Available online: https:/ / www.epa.gov / pm-pollution/particulate-matter-pm-implementation-regulatory-actions.

7. Koppmann, R. Volatile Organic Compounds in the Atmosphere; John Wiley \& Sons: New York, NY, USA, 2007.

8. Mohankumar, S.; Senthilkumar, P. Particulate matter formation and its control methodologies for diesel engine: A comprehensive review. Renew. Sustain. Energy Rev. 2017, 80, 1227-1238. [CrossRef]

9. Gupta, T.; Kumar Singh, D. Organic species emitted as a part of combustion residue: Fate and transformation in the ambient air. J. Energy Environ. Sustain. 2016, 1, 10-18. [CrossRef]

10. Gelles, T.; Krishnamurthy, A.; Adebayo, B.; Rownaghi, A.; Rezaei, F. Abatement of gaseous volatile organic compounds: A material perspective. Catal. Today 2020, 350, 3-18. [CrossRef]

11. Li, X.; Zhang, L.; Yang, Z.; Wang, P.; Yan, Y.; Ran, J. Adsorption materials for volatile organic compounds (VOCs) and the key factors for VOCs adsorption process: A review. Sep. Purif. Technol. 2020, 235, 116213. [CrossRef]

12. Yang, C.; Miao, G.; Pi, Y.; Xia, Q.; Wu, J.; Li, Z.; Xiao, J. Abatement of various types of VOCs by adsorption/catalytic oxidation: A review. Chem. Eng. J. 2019, 370, 1128-1153. [CrossRef]

13. Kamal, M.S.; Razzak, S.; Hossain, M.M. Catalytic oxidation of volatile organic compounds (VOCs)—A review. Atmos. Environ. 2016, 140, 117-134. [CrossRef]

14. Schiavon, M.; Torretta, V.; Casazza, A.; Ragazzi, M. Non-thermal Plasma as an Innovative Option for the Abatement of Volatile Organic Compounds: A Review. Water Air Soil Pollut. 2017, 228, 388. [CrossRef]

15. Veerapandian, S.K.P.; De Geyter, N.; Giraudon, J.-M.; Lamonier, J.-F.; Morent, R. The Use of Zeolites for VOCs Abatement by Combining Non-Thermal Plasma, Adsorption, and/or Catalysis: A Review. Catalysts 2019, 9, 98. [CrossRef]

16. Krishnamurthy, A.; Adebayo, B.; Gelles, T.; Rownaghi, A.; Rezaei, F. Abatement of gaseous volatile organic compounds: A process perspective. Catal. Today 2020, 350, 100-119. [CrossRef]

17. I Khan, F.; Ghoshal, A.K. Removal of Volatile Organic Compounds from polluted air. J. Loss Prev. Process. Ind. 2000, 13, 527-545. [CrossRef]

18. Fino, D.; Bensaid, S.; Piumetti, M.; Russo, N. A review on the catalytic combustion of soot in Diesel particulate filters for automotive applications: From powder catalysts to structured reactors. Appl. Catal. A Gen. 2016, 509, 75-96. [CrossRef]

19. Zhang, Z.; Jiang, Z.; Shangguan, W. Low-temperature catalysis for VOCs removal in technology and application: A state-of-the-art review. Catal. Today 2016, 264, 270-278. [CrossRef]

20. Piumetti, M.; Fino, D.; Russo, N. Mesoporous manganese oxides prepared by solution combustion synthesis as catalysts for the total oxidation of VOCs. Appl. Catal. B Environ. 2015, 163, 277-287. [CrossRef]

21. Santos, V.; Pereira, M.; Órfão, J.; Figueiredo, J. The role of lattice oxygen on the activity of manganese oxides towards the oxidation of volatile organic compounds. Appl. Catal. B Environ. 2010, 99, 353-363. [CrossRef]

22. Spivey, J.J. Complete catalytic oxidation of volatile organics. Ind. Eng. Chem. Res. 1987, 26, 2165-2180. [CrossRef]

23. Haynes, W.M. CRC Handbook of Chemistry and Physics: A Ready-Reference Book of Chemical and Physical Data, 85th ed.; CRC Press LLC: Boca Raton, FL, USA, 2005. 
24. Aguilera, D.A.; Pérez-Flórez, A.; Molina, R.; Moreno, S. Cu-Mn and Co-Mn catalysts synthesized from hydrotalcites and their use in the oxidation of VOCs. Appl. Catal. B Environ. 2011, 104, 144-150. [CrossRef]

25. Delimaris, D.; Ioannides, T. VOC oxidation over $\mathrm{CuO}-\mathrm{CeO} 2$ catalysts prepared by a combustion method. Appl. Catal. B Environ. 2009, 89, 295-302. [CrossRef]

26. Kapteijn, F.; Singoredjo, L.; Andreini, A.; Moulijn, J. Activity and selectivity of pure manganese oxides in the selective catalytic reduction of nitric oxide with ammonia. Appl. Catal. B Environ. 1994, 3, 173-189. [CrossRef]

27. Piumetti, M.; Bensaid, S.; Andana, T.; Russo, N.; Pirone, R.; Fino, D. Cerium-copper oxides prepared by solution combustion synthesis for total oxidation reactions: From powder catalysts to structured reactors. Appl. Catal. B Environ. 2017, 205, 455-468. [CrossRef]

28. Piumetti, M.; Bensaid, S.; Andana, T.; Dosa, M.; Novara, C.; Giorgis, F.; Russo, N.; Fino, D. Nanostructured ceria-based materials: Effect of the hydrothermal synthesis conditions on the structural properties and catalytic activity. Catalysts 2017, 7, 174. [CrossRef]

29. Gandhe, A.R.; Rebello, J.S.; Figueiredo, J.; Fernandes, J. Manganese oxide OMS-2 as an effective catalyst for total oxidation of ethyl acetate. Appl. Catal. B Environ. 2007, 72, 129-135. [CrossRef]

30. Spinicci, R.; Tofanari, A. Characterization of catalysts for methane-coupling by means of temperature programmed desorption. Catal. Today 1990, 6, 473-479. [CrossRef]

31. Li, Z.; Meng, M.; Zha, Y.; Dai, F.; Hu, T.; Xie, Y.; Zhang, J. Highly efficient multifunctional dually-substituted perovskite catalysts La1-xKxCo1-yCuyO3 $-\delta$ used for soot combustion, NOx storage and simultaneous NOx-soot removal. Appl. Catal. B Environ. 2012, 121-122, 65-74. [CrossRef]

32. Andana, T.; Piumetti, M.; Bensaid, S.; Russo, N.; Fino, D.; Pirone, R. Nanostructured ceria-praseodymia catalysts for diesel soot combustion. Appl. Catal. B Environ. 2016, 197, 125-137. [CrossRef]

33. Moulder, J.F.; Stickle, W.F.; Sobol, P.E.; Bomben, K.D. Handbook of X-ray Photoelectron Spectroscopy; Chastain, J., Ed.; Perkin-Elmer Corporation: Eden Prairie, MN, USA, 1992.

34. Kim, S.C.; Shim, W.G. Catalytic combustion of VOCs over a series of manganese oxide catalysts. Appl. Catal. B Environ. 2010, 98, 180-185. [CrossRef]

35. Liu, Y.; Dai, H.; Deng, J.; Xie, S.; Yang, H.; Tan, W.; Han, W.; Jiang, Y.; Guo, G. Mesoporous $\mathrm{Co}_{3} \mathrm{O}_{4}$-supported gold nanocatalysts: Highly active for the oxidation of carbon monoxide, benzene, toluene, and o-xylene. J. Catal. 2014, 309, 408-418. [CrossRef]

36. Zawadzki, M.; Trawczyński, J. Synthesis, characterization and catalytic performance of LSCF perovskite for VOC combustion. Catalysts 2011, 176, 449-452. [CrossRef]

37. Biesinger, M.C.; Payne, B.P.; Grosvenor, A.P.; Lau, L.W.M.; Gerson, A.R.; Smart, R.S.C. Resolving surface chemical states in XPS analysis of first row transition metals, oxides and hydroxides: Cr, Mn, Fe, Co and Ni. Appl. Surf. Sci. 2011, 257, 2717-2730. [CrossRef]

38. Piumetti, M.; Russo, N. Notes on Catalysis for Environment and Energy; CLUT-Politecnico di Torino: Turin, Italy, 2017.

39. Dosa, M.; Piumetti, M.; Bensaid, S.; Andana, T.; Novara, C.; Giorgis, F.; Fino, D.; Russo, N. Novel Mn-Cu-Containing CeO 2 Nanopolyhedra for the Oxidation of CO and Diesel Soot: Effect of Dopants on the Nanostructure and Catalytic Activity. Catal. Lett. 2017, 148, 298-311. [CrossRef]

40. Figueredo, M.J.M.; Andana, T.; Bensaid, S.; Dosa, M.; Fino, D.; Russo, N.; Piumetti, M. Cerium-Copper-Manganese Oxides Synthesized via Solution Combustion Synthesis (SCS) for Total Oxidation of VOCs. Catal. Lett. 2020, 150, 1821-1840. [CrossRef]

41. Piumetti, M.; van der Linden, B.; Makkee, M.; Miceli, P.; Fino, D.; Russo, N.; Bensaid, S. Contact dynamics for a solid-solid reaction mediated by gas-phase oxygen: Study on the soot oxidation over ceria-based catalysts. Appl. Catal. B Environ. 2016, 199, 96-107. [CrossRef]

42. Deorsola, F.; Andreoli, S.; Armandi, M.; Bonelli, B.; Pirone, R. Unsupported nanostructured Mn oxides obtained by Solution Combustion Synthesis: Textural and surface properties, and catalytic performance in NO x SCR at low temperature. Appl. Catal. A Gen. 2016, 522, 120-129. [CrossRef]

43. Wagloehner, S.; Nitzer-Noski, M.; Kureti, S. Oxidation of soot on manganese oxide catalysts. Chem. Eng. J. 2015, 259 , 492-504. [CrossRef]

44. Wagloehner, S.; Baer, J.N.; Kureti, S. Structure-activity relation of iron oxide catalysts in soot oxidation. Appl. Catal. B Environ. 2014, 147, 1000-1008. [CrossRef] 